\title{
HELPFUL MODELS OF THEOLOGICAL, MORAL, AND SPIRITUAL DISCERNMENT IN CATHOLICISM, PROTESTANTISM, AND ORTHODOXY*
}

K A T E Ř I A K O Č A N DRLE B A UER, F R A N T I ŠE K Š T Ě C H, M I C H A E L A K UŠ N I E R IKOVÁ

\begin{abstract}
This article deals with the theme of the discernment of good and evil from the perspective of three Christian traditions. It is written in a form of a dialogue between three authors, where each represents the voice of one Christian tradition. Dialogue is not just an important part of theological discourse but also an essential element of every kind of discernment since it creates space for a non-fundamentalist approach to truth about God, oneself, and the world. For a better understanding of the conversational flow, which sometimes leads us to associated themes, the article is divided into five parts. Firstly, it speaks about the difference between theological, moral, and spiritual discernment. Secondly, it concentrates on discernment in connection with the different concepts of redemption. Consequently, the article deals with the discernment of good and evil in relationship with the origin of evil. Lastly, it elaborates the present and eschatological aspects of discernment and the role of individuals and community in the process of how Christians discern.
\end{abstract}

\section{Key words}

Discernment; Evil; Good; Dialogue; Christian traditions; Eschatology; Pneumatology; Ascesis

DOI: $10.14712 / 23363398.2020 .5$

* This article is supported by Charles University Research Centre No. 204052. František Štěch's part was also supported by Charles University grant Primus/Hum/23. 
$\mathrm{I}_{\mathrm{n}}$ our article, we will speak about the discernment of good and evil from the perspective of three Christian traditions. It is written in a form of a dialogue between the three of us. We are aware that this is not a usual form in the contemporary academic discourse within the humanities. ${ }^{1}$ However, it was not just an important style of philosophical and theological questioning in the past, ${ }^{2}$ but also a fundamental part of every discernment. Discernment is dia-logos: one gains knowledge about reality via exchanging the logos (logoi) with oneself and others but also with the whole cosmos. The real dialogue forces us to let ourselves be, to let Ego go and thus create space for a non-fundamentalist approach to truth about God, oneself, and the world. For a better understanding of the conversational flow, which sometimes leads us to other associated themes, the text has been divided into five parts.

\section{Part I: The Difference between Theological, Moral, and Spiritual Discernment}

M: Is there any difference between theological, moral, and spiritual discernment?

F: I think that a distinction between theological, moral, and spiritual discernment is possible; however, it is merely a technical distinction based on the decision to accent a particular aspect of the singular discernment, a process which is always composed of all three components. In reality, theological, moral, and spiritual discernment cannot be separated, but in theory we may consider each of them as a particular access point to the human praxis of discernment, which is commonly understood as an 'art of perceiving differences' process of inquiry of what is true and false, right and wrong, and what action actually does good and what does bad.

1 See, for example, Ivana Noble, Anne-Marie Reijnen, and Kateřina Bauerová, 'Newness in Theology: How to Tell a Fashion from a Paradigm Shift,' Cursor: Zeitschrift für explorative Theologie, accessed December 4, 2019, https://cursor.pubpub.org/pub /noble-newness-2017?version=44daceeb-2f71-4f10-bc7e-f8043577fa92.

2 Let us recall here Plato's dialogues or Thomas Aquinas's Scholastic style of his Summa.

3 Michael G. Lawler and Todd A. Salzman, 'Moral Theology and the Will of God - Critical Discernment,' The Furrow 63, no. 10 (2012): 484. 
K: Can you think of any theological figure from contemporary Roman Catholic theologians whose theology describes the art of perceiving differences in a helpful way for us?

F: I think Karl Rahner could serve here as a profound example. ${ }^{4}$ Rahner holds a possibility of an immediate human experience of God and supports this insistence by a theology of grace, which is to a great extent based on Ignatian discernment helping people to discover where God is acting in their lives. ${ }^{5}$ According to Rahner's concept of supernatural existential, people are created after the image and likeness of God, and through the very act of creation God communicates himself to people as a loving and generous discerner, the one who discerns and elevates human nature above all other natures through granting them the supernatural existential. ${ }^{6}$ Consequently, human beings are also capable of discernment. It might be perhaps said that they are even called to discernment in order to discover God, their creator, and to enter into a relationship with Him. Discernment is what human beings have in common with God, yet judgment (about what is finally good and evil) remains reserved for the Creator.

K: Do you mean that all three aspects of the discernment are given to people as a potentiality?

F: As we said earlier, discernment has not only a moral level but also two other levels: theological and spiritual. For me, it appears that while moral discernment in the Roman Catholic tradition is connected to practical reason (ratio practica), theological discernment relates more to theoretical reason (ratio theoretica). While practical reason is focused on the discernment of what one is to do, theoretical reason discerns what one ought to believe.

K: For me, the Kantian or earlier Aristotelian distinction of two reasons can be a helpful model only to some extent as it does not speak about spirit and spiritual discernment or, for example, about the heart as one of the organs making decisions or about the human senses: the eyes, ears, or nose.

4 Some authors speak of Rahner's theology as about the 'anthropological turn' in theology. See, for instance, Anton Losinger, The Anthropological Turn: The Human Orientation of the Theology of Karl Rahner (New York: Fordham University Press, 2000). Cf. John J. O'Donell, Karl Rahner: Life in the Spirit (Roma: E.P.U.G., 2004), 27.

6 Rahner's expression 'supernatural existential' is a substantive which refers to an element of human existence, which is an offer of grace. See Karl Rahner, 'Über das Verhältnis von Natur und Gnade,' in Schriften zur Theologie 1 (Einsiedeln: Benziger, 1954), 323-345. 
F: Indeed, I agree with you. Right here one may raise an objection that using theoretical and practical reason in the theological and moral sphere has nothing to do with discernment because it is just reasoning. True theological as well as theologically motivated moral discernment needs a connection to spiritual life or spirituality, which provides the last necessary dimension to the human capacity of discernment. And precisely here we may find a link to the Holy Spirit at work in human discernment. As, for instance, I can mention Dawn Nothwehr, who, in his article on the relation between discernment of spirits and moral choice in the Roman Catholic tradition, claims: 'In our pluralistic, fearful, ecologically threatened world, Catholics need to reclaim the significant role of the life-giving and communion-building Holy Spirit in empowering, sustaining, and enabling them to make moral decisions. ${ }^{7}$ And the same may be true for theology as well. Without the significant role of the Holy Spirit each theology can appear only as dry reasoning with no ability to ignite or sustain the fire of faith in human beings. Thus, in connection to Nothwehr's relating the Holy Spirit to moral decisions, I would like to underline that spiritual discernment (discernment of spirits) is the third necessary component of the human capacity of discernment which maintains the desired synergy between theological, moral, and spiritual life.

F: Even though there is a principal synergy among theological, moral, and spiritual life and discernment, there are also differences to be perceived. I would like to ask you, what is your opinion on the difference among those three aspects?

K: I also agree with you that the three aspects of discernment are very difficult to split apart in praxis. I even see a kind of danger in separating the spiritual ability of discernment from the ethical part of our behaviour and moral discernment, and vice versa. I can imagine how the two aspects when separated end up in two extremes: 'spiritualizing' reality without being aware of corporality and immanence of it, and 'moralism' without any discernment of the particular embodiment in space and time. In the Orthodox tradition, you find the description of the steps of spiritual growth that always contain practical, theoretical, and mystical steps. ${ }^{8}$ Even if they are called steps, they never

7 Dawn M. Nothwehr, 'By the Power of the Holy Spirit Discernment of Spirits and Moral Choice,' New Theology Review 20, no.1 (2007): 18.

8 Sometimes the three stages or steps are called: purification (katharsis), illumination (photisis), and perfection (teleiosis). 
exist separately. In patristic terminology, theoria is more contemplating Scripture or creation, but it is also the inner ability to see God. Even if it somehow transcends the practical part as, for example, fasting, cleansing of passion, at the same time theoria never leaves praxis behind. You find the same emphasis in the contemporary Orthodox authors such as Dumitru Stăniloae ${ }^{9}$ or Kallistos Ware. ${ }^{10}$ The spiritual discernment of good and evil thoughts is possible only together with practical doing. ${ }^{11}$

F: But what about theological discernment?

K: I think that the same is valid for theological discernment. You can gain a university degree in theology but still have no ability of spiritual discernment. ${ }^{12}$ But ideally, in the stage of theoria knowledge of God is also a communion with God so theology becomes spirituality. Here, I agree with Father Sophrony Sakharov (1886-1993), who recognises two types of theology: the first type of theology ends up in pure abstract concepts without any 'knowing Christ in the heart' and the other which is always connected with prayer and brings not just knowledge but also wisdom. ${ }^{13}$

F: And do you find here some example of this in the modern theologians who managed to combine all three aspects or, in your words, all three steps?

K: Well, the third step as the mystical one connected with perfection is hard to judge since perfection is mostly an eschatological category. But I can think of one person - Mother Maria Skobtsova, ${ }^{14}$ who is for me an example of someone who managed to combine the

9 Dumitru Stăniloae, Orthodox Spirituality: A Practical Guide for the Faithful and a Definitive Manual for the Scholar (South Canaan: St. Tikhon's Seminary Press, 2002), 69.

10 Kallistos Ware, The Orthodox Way (Crestwood: St. Vladimir's Seminary Press, 1986), 140-177; Stăniloae, Orthodox spirituality, 40-45.

11 Stăniloae, Orthodox spirituality, 69-70.

12 See Fr. Theodore G. Stylianopoulos, Gospel, Spirituality and Renewal in Orthodoxy, accessed March 22, 2019, http://www.intratext.com/IXT/ENG0823/_P13.HTM.

13 Father Sophrony Sakharov, On Prayer (Essex: Stavropegic Monastery of St. John the Baptist, 1996), 62.

14 For more details about her life, see, for example, Xenija Krivošejna, Мать Мария (Скобиова): Святая наших дней [Mother Maria (Skobtsova): A Saint for Our Time] (Moscow: Eksmo, 2015); Kateřina Bauerová, 'Emigration as Taking Roots and Giving Wings: Sergei Bulgakov, Nikolai Berdyaev and Mother Maria Skobtsova,' Communio Viatorum 54, no. 2 (2012): 184-201; Kateřina Kočandrle Bauer, 'Emigration as a Space for Creative Freedom: Mother Maria Skobtsova and Sister Joanna Reitlinger,' Journal of the European Society of Women in Theological Research 26 (2018): 95-107. 
spiritual, practical, and mystical in her life. Her specific vision of monastic life came out of the context she lived in. She came to Paris as a refugee after the 1917 revolution in Russia. She represents a special monastic life in the city without a monastery. She calls for the true monastic non-possession, which means even the non-possession of one's own image about the right, exclusive way of monastic life. From the context of exile in France, she criticised even the Hesychast practice of Mount Athos as being too concentrated on the monk's own spiritual hygiene while being far from the 'sinner' and the world. ${ }^{15}$ For her, monasticism does not mean to escape the world but rather to live within it. Spiritual discernment is also ethical or practical and mystical at the same time. ${ }^{16}$

K: Michaela, are the theological, moral, and spiritual only aspects of one discernment or not for you?

M: I agree with you both that theological, moral, and spiritual discernment are intertwined since in all of them we examine our experience, but foremost, strive to understand God's revelation and presence in various contexts of our world and lives. For me, each of the three discernments consists of dialogue, of which listening is a crucial part. Listening to those with whom we share not only hymns and pews but the world, lives, our concerns, and ideas regardless of whether they are Christian, religious, agnostics, or atheists is a crucial aspect of any thinking process. For me, it is important to keep in mind that none of the discernments is purely a human undertaking since God remains the free agent of God's own revelation(s). ${ }^{17}$ Any reflection of faith is based on God's acting in the world primarily in Christ who became a sinner for us, lived, died, rose and ascended for us. ${ }^{18}$ According to

15 See Mother Maria Skobtsova, 'Types of Religious Life,' in Mother Maria Skobtsova: Essential Writings (Maryknoll: Orbis Books, 2003), 140-186; here 154.

16 To meet God's image in humanity was for her seen as meeting the mystery of the Incarnation and God-man-hood. See Mother Maria Skobstova, 'The Second Gospel Commandment,' 57.

17 Wolfhart Pannenberg, Systematic Theology 1, trans. Geoffrey W. Bromiley (London, New York: T\&T Clark, 2004), 4-8.

18 As Luther said in one of his Christmas sermons: 'We do not believe that the virgin mother bore a son and that he is the Lord and Saviour unless, added to this, I believe the second thing, namely, that he is my Saviour and Lord. When I can say: This I accept as my own because the angel meant it for me, then, if I believe it in my heart, I shall not fail to love the mother Mary, and even more the child, and especially the Father.' Martin Luther, 'Sermon on the Afternoon of Christmas Day 1530,' in Martin Luther's Basic Theological Writings, ed. Timothy F. Lull (Minneapolis: Fortress Press, 2012), 232. 
Luther, ${ }^{19}$ each person needs salvation of their whole being, including reason, spirit, and conscience. The word of God, coming to us from the outside in the word and Sacraments, is the counsel we need in examining any aspect of our spiritual and life journeys. Therefore, to him, any discernment needs to start with redemption - with divine intervention in a person's whole being and life. Accordingly, it would be probably a bit artificial for him to divide this theological discourse into three separate divisions since the criteria for any discernment for him is and remains the word of God.

\section{Part II: Discernment as Connected to the Concept of Redemption: Justification and Deification?}

K: For me, Luther's anthropology and cosmology do not provide any space for the co-operation of people and God in the journey of salvation and the potentiality to discern out of human nature.

M: The Fall has left its marks upon this world - human and natural. However, I think there is space for co-operation in a person's life towards salvation - to live a life of sanctification, without salvation becoming merit. Sanctification is a life united with God, a life accepting and living out Christ's presence within a person through the Holy Spirit. Thus, this life has a different source - participating in the life of Christ, living a full life. I think it might be helpful to distinguish between theological and psychological aspects of divine action in human beings. One is not forced to accept God's grace. A person obeys the call to follow Christ and strives to search for God's will. Theologically speaking, one can set out and grow on the journey of salvation only through the work of the Holy Spirit. The Decalogue is the framework of such life and at the same time 'we also need it to discern how far the Holy Spirit has advanced us in his work of sanctification and by how much we still fall short of the goal' ${ }^{20}$ Luther distinguishes between our effort and its progress or failing and the work of the Holy Spirit in us. I keep Luther's suspicion of conscience and reason on their own (unredeemed) together with his two kingdoms doctrine, which claims that people outside of the Christian faith are able to make reasonable

19 Cf. LW 32, 112-113; LW 27, 387.

20 Martin Luther, 'On the Councils of the Church,' in Martin Luther's Basic Theological Writings, 563. 
and even moral choices based on the use of their reason. Such reason, however, would not be able to shed light on theological and/or spiritual questions.

K: Can you think of any contemporary Protestant theologian, who would bring a more positive anthropology and who speaks about people's potentiality and ability to discern?

M: I find a very helpful model in the works of the Lutheran theologian Dorothee Sölle. In her book Beyond Mere Obedience, she makes a distinction between automatic obedience blinded towards the world from discerning the will of God in a creative way, which takes into account not only God's command but also human responsibility and specific life situations. ${ }^{21}$ Following the story of Jesus, she says, we are liberated and transformed for a life of happiness, which is a fulfilled life. It is marked with fantasy and spontaneity within the human community. God's liberation consists in freedom from a view of God's will that is thoughtless and devoid of creativity. Therefore, discernment could concern also the concept of sin in connection with human imagination, integrity, and happiness.

As I said, the potential for moral discernment remains also for non-Christians, even though not in its fullness. Those who continue to live in sin, they live a life of disunity, estrangement - from God, themselves, others, and the world. For example, Dietrich Bonhoeffer says that even the conscience of a person living in sin, in the Old Adam, is attempting self-justification and self-purification..$^{22}$ Once united with Christ, the human will is liberated from worrying about one's own pure conscience but gives the freedom to live for others and, if necessary, become guilty in that life. ${ }^{23}$ Since the concepts of the forgiveness of sins and new life in Christ are exposed primarily in the theological discourse, I consider it as having a certain primacy among the three discourses.

21 Cf. Dorothee Sölle, Beyond Mere Obedience: Reflections on a Christian Ethic for the Future (Minneapolis: Fortress Press, 1970).

22 Cf. Dietrich Bonhoeffer, 'Akt und Sein: Transzendentalphilosophie und Ontologie in der systematischen Theologie,' in Dietrich Bonhoeffer Werke 2, ed. Hans-Richard Reuter (München: Christian KaiserVerlag, 1988), 110-111. Bonhoeffer describes human conscience as 'a binding call of the human existence towards unity with itself'. See Dietrich Bonhoeffer, 'Ethik,' in Dietrich Bonhoeffer Werke 6, ed. Clifford Green, Ilse Tödt, Heinz Eduard Tödt and Ernst Feil (München: Christian Kaiser Verlag, 1998), 277.

23 Dietrich Bonhoeffer, Letters from Prison (New York: Macmillan, 1972), 4. 
K: You use the vocabulary as 'sin' or 'sinful', which is connected to the concept of redemption as justification. For me salvation is more the journey of people with God. This journey means to become deeply human, not to transcend what is human, but it is rather the fulfilment of it. Therefore, I still have a question whether some of the principles of Orthodox morality and moral discernment might differ from the Protestant and Catholic approach because of a different conception of original sin, a different interpretation of redemption as seen more as deification?

F: I estimate that there will be no difference in general Christian moral principles, but it may differ in their interpretation. And it is precisely because of the notion of theosis as you suggest, Kateřina. The Roman-Catholic tradition may differ from the Orthodox in the concept of peccabilitas - the principal ability to $\sin .{ }^{24}$ This term, is not of biblical origin but rather of a philosophical-theological nature. The Bible uses the term concupiscence or desirousness (concupiscentia), which is not a term identical to sin, but it suggests an openness or possibility to $\sin .^{25}$

K: Yes, it is true that deification (theosis) has been used as the distinctive teaching of the Orthodox Church and stands in the contrast to the teaching about justification. The possibility of human synergic work in deification comes out of positive anthropology but also cosmology. Here, the Orthodox priest and theologian Sergei Bulgakov inspires me a lot when he speaks about the theme of grace in connection with

24 See, for instance, Vladimír Boublík, Teologická antropologie (Kostelní Vydří: Karmelitánské nakladatelství, 2006), 92-96.

25 There is a long tradition of interpretation of the notion of peccabilitas starting from St. Augustine, who inclined to identify concupiscence with original sin. Going through medieval theology, this maintained the physical (bodily) character of concupiscence but did not identify it with sin. This is, according to Boublík, especially visible in the theology of St Thomas for whom concupiscence is essentially good (because it is spontaneous), but in principle allows for sin if it is influenced by temptation and not by the Spirit and grace. See Boublík, Teologická antropologie, 93-94. In fact, peccabilitas, as the real possibility to sin and as part of human createdness cannot be overcome by any human powers, only by Christ's grace. In other words, creation must be transformed from within by the creator itself so that the ability to sin might be finally cancelled and not able to condition people anymore. This is, however, identical with the eschatological transformation of human beings through salvation - through the climax of the process of human deification. While the first Adam (archetypal human) ate from the tree of knowledge, through salvation in Jesus Christ (the second Adam), who overcame peccabilitas, the new creation will eat from the tree of life. Cf. František Štěch, Tu se jim otevrely oći: Zjevení, víra a církev v teologii kardinála Avery Dullese, SJ (Olomouc: Refugium, 2011), 108. 
deification. Instead of 'original sin' he speaks about 'original grace'. ${ }^{26}$ He also denies the categorisation of 'natural grace' and 'supernatural mercy'. ${ }^{27}$ For him, the only distinction that has to be made is between created being and grace that is of divine character. But between these two there has to be a positive attitude from both sides; otherwise it would be violence of God on creation. ${ }^{28}$ Here Bulgakov emphasises the role of the Holy Spirit whose power was already present at the moment of creation, and through the Holy Spirit we can participate in the natural mercy of God's creation. ${ }^{29}$

M: There has been an ongoing Lutheran-Orthodox ecumenical dialogue focusing on the different interpretations of redemption in those traditions. For example, the Lutheran-Orthodox Joint Commission has elaborated on the concepts of theosis and justification, synergy and personal responsibility, stating that 'Lutherans, together with the Orthodox, affirm that salvation is real participation by grace in the nature of God', Lutheran theology has a tendency to emphasise God's unmerited grace by using the term forensic justification and talks about sanctification (not using the term theosis) when dealing with a new life in Christ. There is a true notion of transformation expressed with that concept. Moreover, 'Lutherans and Orthodox both understand good works as the fruits and manifestations of the believer's faith and not as a means of salvation' ${ }^{30}$ Thus, this document identifies distinct terminology (justification and theosis) in both traditions, expressing salvation while emphasising common theology that is behind them.

26 See Paul Vallier, Modern Russian Theology: Bukharev, Soloviev, Bulgakov: orthodox Theology in a New Key (Edinburgh: T\&T Clark, 2000), 352.

27 Sergei Bulgakov, Невеста Агнеия: O bogochelovechestve (Paris: YMCA, 1945), 318-328 and Sergei Bulgakov, Утешитель. О Богочеловечестве. часть II (Paris: YMCA, 1936), 233-251.

28 See Bulgakov, Невеста Агнеия: O bogochelovechestve, 320.

29 See Bulgakov, Утешитель, 233-251.

30 'Authority in and of the Church in the Light of the Ecumenical Councils,' 9th Plenary of the Lutheran-Orthodox Joint Commission, Sigtuna/Sweden (31 July - 8 August 1998), accessed March, 22, 2019, https://www.lutheranworld.org/sites/default/files/1998 -Lutheran_Orthodox_Dialogue-EN.pdf.

What is also distinct is the explanation of how this participation in divine life takes place. The Orthodox tradition talks about divine energies, while the Lutheran tradition does not use this distinction between the divine essence and divine energies. Cf. ibid. 


\section{Part III: The Ability to Discern Good and Evil Related to the Question of the Origin of Evil}

M: The discernment of good and evil is connected with the question of the origin of evil. In your opinion, is evil something or someone? Is discernment a matter of human free will and God's grace without any influences of the angelic world?

K: Well, here, Augustine's idea of evil as privatio boni ${ }^{31}$ has been followed by centuries up to today by the whole Christian world. The Orthodox theologian Kallistos Ware interprets evil from the Orthodox point of view on the basis of the fall in two stages: first the angelic fall and then the human fall. He points out three important consequences of it: firstly, besides the evil for which we humans are personally responsible, there are forces whose will is turned to evil in the universe. Secondly, fallen spiritual powers help us to understand why, prior to man's creation, there should be disorder or waste found in the world of nature. Thirdly, the rebellion of angels makes it clear that evil originates not from below but from above, not from matter but from spirit. Some others, as for example Nikolai Berdyaev, concentrate more on evil as the result of human free will and thus as a part of human discernment between good and evil. He emphasises that good and evil are different categories of reality. These two principles cannot be compared - as absolute and relative they cannot stand in real opposition. ${ }^{32}$ 'Evil means the falling apart of the absolute being, which happened only because of freedom' and freedom is the basic internal attribute of every being, which is created according to God's image and likeness. ${ }^{33}$

F: As far as I can see, it is both. A person as well as an act can be evil. I am not sure about objects. Perhaps weapons? Is a nuclear weapon evil per se? In Hebrew, Satan is 'adversary' - that means it could be anyone. See, for instance, Matthew 16:22-23. Jesus calls Peter 'Satan'. Humanity has both principal inclinations to good and to evil. As far as

31 Augustine, Confessions, VII.

32 To compare them we might end up in Manicheism with its dualistic cosmology. See Nikolai Berdayev, Filosofie Svobody: Pưvod a smysl déjin [Philosophy of Freedom] (Votobia, 2000), 20.

33 Another example is Vladimir Lossky in his Dogmatic Theology, who sees evil not only as mere passivity, but he sees evil as active. For him evil is not something, it is not a thing, it is who. Evil is personal. See Vladimir Lossky, Orthodox Theology: An Introduction (Crestwood: St. Vladimir's Seminary Press, 1978), 79-81. 
humanity is created after the image and likeness of God, we are free to choose which way we go. And it is not once and for all that we make many choices in our lives. Sometimes we are 'Satans for ourselves'. I believe our own (selfish) desires are the worst enemies or adversaries we must fight in our lives. I can become evil by decision and, if that is the case, what I do and create is evil too. But all evil might be turned into good by God in one way or another. Here, another question arises if evil is the same as sin.

M: This last sentence is an important question for me - what is the relation between evil and sin? And how we can discern evil as such? I am drawn to the book by Edward Farley Good and Evil, where he writes:

Human evil is never a discrete and isolated corruption, a demonic inhabitation, or a piece of human ontology. It is a network of occurrences that varies with every agent, situation and period of time. [...] An agent's posture of enmity will always reflect the subjugations and relations of that time and place and will be embodied in the agent's unique autobiographical and developmental situation. The same holds for specific relations and institutions. ${ }^{34}$

He traces evil to the tragic character of the human condition in that the structure of human reality is such that 'agents, relations, and institutions obtain and maintain their goods only in conjunction with all sorts of intrinsic limitations, exclusions, and sufferings'.$^{55}$ Thus, it is not so much about inclinations or a person's dispositions, in his opinion. It is about the structure of the human condition that is formed by three interrelated spheres - interhuman, social, and interpersonal. Each of them is marked by isolation and the tragic structure. So, I guess, drawing on Farley, I would say evil is rather something.

F: Is good the only alternative to evil? Is there anything in between? Am I good or bad? Or am I both? This anthropological condition influences our discernment, which does not have to be necessarily only discernment between good and evil, but also discernment between good and even better or between different levels of goodness.

\footnotetext{
34 Edward Farley, Good and Evil: Interpreting the Human Condition (Minneapolis: Fortress Press, 1990), 286

35 Ibid., 29.
} 
K: I like your question very much as, so far, we have spoken in the dualistic language of good and evil because in our mind discernment is strongly connected to dualism. However, sometimes we have to discern between good and better or the best, and already here theological anthropology plays an important role. Orthodox tradition more than the Protestant one, I guess, emphasises first of all the Edenic image of God in people, and already after this we have two falls as I described earlier. But even the Orthodox tradition does not forget that sin exists within people, and they are a mixture of good and evil. We are not only God's image, but we are also sinners. The Orthodox theologian Olivier Clément speaks about people as sinful mortals but at the same time as about kings. ${ }^{36}$ This is our fragile existence; this is the state in which we live, and we discern out of this fragility.

M: From the Protestant perspective I think of Luther here and his notion of the existence of every Christian as being simul iustus et peccator - justified and sinner at the same time. Every day, they need to die and be born again with Christ. ${ }^{37}$ Thus, they are always as if they are in-between. They are redeemed sinners, which does not automatically make them into good people and/or immune to evil deeds, thoughts, or words. Theologically and spiritually they are united with Christ, and thus born-again sinners - every day, they are crucified and rise with Christ. I think Luther did not talk about specifically good or bad, but the constant need of Christians to look at Christ's cross and resurrection instead of despair or pride of their deeds.

F: And is it the same theologically and morally?

M: I would say, theologically, human beings in Christ are justified sinners while morally they might do both, even simultaneously, good and/or evil. Their unity with the New Adam does not automatically condone their moral discernment or action since their struggle with the Old Adam for sanctification continues.

K: Concerning the ability to discern we have to clear up whether evil is really a part of human nature or whether it depends on human free will.

${ }^{36}$ See Oliviér Clément, Télo pro smrt a slávu: malé uvedeni do teopoetiky téla (Velehrad: Refugium, 2004), 10.

37 Cf. Martin Luther, Lecture on Romans (Louisville: Westminster John Knox Press, 2006), 322-323. For a discussion of the concept within Luther's historical context, see Scott H. Hendrix, Martin Luther: Visionary Reformer (New Heaven and London: Yale University Press, 2015), 111-112. 
F: I would think both. I would say an inclination to evil is present in everyone in potential. The question of free will is whether we will develop this potential or deny it.

$\mathbf{K}$ : If evil is part of our nature, which is completely corrupted, then only those redeemed can participate in God's salvific actions, and only those redeemed have power to discern. There is a sharp division between church and the world. To answer the question, perhaps we need to start from the issue of original sin and its interpretation. Within the Orthodox tradition the teaching about pecatum heareditorum has never been so much developed as in the Roman Catholic tradition and also it has never had only personal consequences as Michaela emphasised above by commenting on Farley. The fact that people were made according to God's image and likeness stands before their corruption, which is important. And also, human free will, which after the angelic world caused the fall, influenced not only humans but the whole cosmos. The original harmony of people but also the original harmony of the whole cosmos was disturbed. Death (thanatos) and corruption (pthora) touched the whole cosmos, as Andrew Louth reminds us. ${ }^{38}$

M: As I have mentioned earlier, instead of focusing on human nature, I prefer to reflect on human beings conditioned by the Fall, thus having an inclination to perceive God and the world through the filter of themselves.

Because of this human egoism Bonhoeffer refused to talk about good and evil as a starting point of Christian ethics. He claims questions such as 'how to be good', 'what is the good I need to do' repeat the aspirations of Adam and Eve that led to the Fall. Christian theology inquires about the will of God, which is a question beyond the knowledge of good and evil. This will is embodied in the person of the God-Man creating a new reality. This is the starting point of moral discernment, not the reality of one's own 'I', of the world, norms, or values. Bonhoeffer puts into contrast the aim of the Old Adam to knowing good (and evil), with the question of the new person - what is the will of God? This inquiry surpasses the sinful attempt to be like God, an attempt to better the world or be good. Seeking the will of God has only the reality of God in the world in its focus. ${ }^{39}$

38 See Andrew Louth, Introducing to Orthodox Theology (London: SPCK, 2013), 73.

39 Cf. Bonhoeffer, 'Ethik,' 31-33. 
F: I think that the origin of evil is any selfishness. It is a sin. I think the history of salvation has not only a dynamic of salvation but also a dynamic of sin, and that dynamic unveils a presence and the nature of evil in the history of all creation. It starts with the original sin, which I would identify with pride. The first people wanted to be not like God but the same as God. Christian theology holds that, at the beginning, everything was created out of the love of God, and through this love (Christ, the logos), the Creator's revelation of God's loving nature opens up its salvific-historical dynamic. But the original love relationship between God and humankind is perverted by the pride of original sin. In the Christian tradition, the symbol of eating the fruit from the tree of the knowledge of good and evil in the Garden of Eden symbolises this original sin (Genesis 2:9). That fruit is commonly associated with an apple. Maybe, it is due to resemblance of the Latin words for apple and evil (malum). But as, for instance, Jan Samohýl points out ${ }^{40}$ in Jewish, rabbinic tradition this mythical tree of the knowledge of good and evil is sometimes interpreted as an etrog tree (hadar). Etrog is a kind of citrus fruit (Citrus medica) which is called in Hebrew peri ez hadar (or else pri etz hadar) ${ }^{41}$ literally the fruit of the beautiful tree. This fruit has a shape like a human heart and because of that shape it symbolises the heart during the Jewish feast Sukkot in its ritual bouquet called Lulav. ${ }^{42}$ Such an interpretation comes most probably from rabbinic commentaries on the Midrash Vayikrah Rabba 30:14. ${ }^{43}$ Lulav consists of a palm leaf, a willow branch, myrtle, and the etrog fruit. In this context, the story of Genesis gains a new dimension. The first people were seduced by the wily (crafty) serpent not to eat just some apple but their own

40 Cf. Jan Samohýl, Židovské inspirace krest’anství (Kostelní Vydří: Karmelitánské nakladatelství, 2017), 104.

41 This transcription is used, for instance, by Daniel Feldman in his article 'Sukkot: Pri Etz Hadar,' accessed March 21, 2019, http://www.mazornet.com/holidays/Sukkot /pri-hadar.htm.

42 This interpretation is mentioned, for instance, by David Brofski in his book Hilkhot Mo'adim: Understanding the Laws of the Festivals. See David Brofsky, Hilkhot Mo'adim: Understanding the Laws of the Festivals (Jerusalem: Koren Publishers, 2013), 299; see also this use by Rivka C. Berman, Sukkot, The Lulav and the Etrog, accessed March 21, 2019, http://www.mazornet.com/holidays/Sukkot/lulav.htm. The same interpretation could be found also in the article by Rabbi Scheinerman, 'Sukkot: The Harvest Festival,' accessed March 21, 2019, http://scheinerman.net/judaism /Holidays/index.html.

43 Cf. Rivka C. Berman, Sukkot: The Lulav and the Etrog, accessed March 21, 2019, http://www.mazornet.com/holidays/Sukkot/lulav.htm. 
heart. And, if we eat our own heart, are we not losing the ability to love? The only thing God wants from his people is their love. But what can they give when they have gaping wound in place of their heart? Human love always requires God's intervention and help. 'I will give you a new heart and put a new spirit in you; I will remove from you your heart of stone and give you a heart of flesh' (Ezekiel 36:26), calls God through the mouth of the prophet Ezekiel.

K: I like this interpretation very much. It reminds me of the praxis of the Jesus prayer of the Hesychast tradition, which is also called the prayer of our heart. Our renewed heart decides and discerns. But the renewed heart is not a mere state but the whole journey, where the cleansing of our heart takes place. In the Orthodox tradition, there is an emphasis on the ascetic practice of the cleansing of our heart from all passions and all images, which is accompanied by repentance. ${ }^{44}$ But of course, the cleansing of the heart is not an end in itself, as it brings a renewed relationship with God, others, and the whole creation.

M: It is the heart open for others, yet not forcing itself upon others. From the Christian belief that human beings are created in the image of God, Bonhoeffer draws the concept of analogia relationis - we are created to live in relation to God and to others. That is the intended human freedom - to be for others. However, to break the limits - the boundaries of the other, to disrespect them - is sinful. One of the fundamental limits is to be human, not to want to be like God. Otherwise, we want to live at the expense of the other. To break the limits of God, of ourselves, other people, and nature is sinful. Pride and egoism make the worldly community - between God and people, themselves and nature - impossible. God enters into the middle of the world in Christ to re-establish the limit and simultaneously, to be at the centre of the world's existence, taking sin and its evil upon himself to free us from them giving us new hearts. Thus, the new community (embodied in the church) is created. ${ }^{45}$

44 See Tomáš Špidlík, Spiritualita krestáanského Východu: modlitba (Velehrad: Refugium, 1999), 339-377.

45 Cf. Dietrich Bonhoeffer, Schöpfung und Fall, in Dietrich Bonhoeffer Werke 3, ed. Martin Rüter and Ilse Tödt (München: Christian Kaiser Verlag, 1989), 60. 


\section{Part IV: The Discernment of Good and Evil: Present and Eschatological Aspects}

M: How does the goal of discernment, as you perceive it, affect the process of discerning?

K: Yes, we have to consider the final thelos of the struggle between good and evil, which is the victory of the Kingdom of God. Then the struggle is a part of the process of deification, which means the co-operation of God and people, and thus also the discernment of what is good and what is evil is necessary here. But the battle between good and evil does not happen only on the spiritual level of the fallen angels, or in the hearts of people or society, it also happens on the level of nature itself. As I said, the fall in the angelic and human spheres brought disharmony for the whole creation, thus the final victory also concerns the whole creation. Therefore, we need also a broad understanding of deification that would include all levels of the cosmos. A helpful model is provided here by the most significant figure of the Russian religious philosophy Vladimir Solovyov. The process of deification, of the unification of God and human, includes not just people themselves (the struggle for their own soul) but also biological development and human culture and history. ${ }^{46}$ The process of deification towards the final victory of God is not a privilege of people, but they are privileged in their discernment together with God to contribute to the transformation of all reality into the divine.

F: If there is a struggle at all ... But perhaps there is. It may be happening within (inside) created creatures who are able to make free decisions. I do not think that there is a dualistic struggle between good and evil, like in Zoroastrianism, for instance, ${ }^{47}$ but there is a struggle between good and evil within persons and consequently also within the created world but that kind of struggle depends on morals and does not have a 'cosmic (or cosmological) relevance'.

M: Even if we know that the hermeneutical key of the struggle comes from the future, how does spiritual discernment look like in praxis?

46 See Kateřina Bauerová, 'The Mysticism of Pan-unity: Sophiology Revisited,' in Wrestling with the Mind of the Fathers, Ivana Noble et al. (Yonkers: St Vladimir's Seminary Press, 2015), 174-185.

47 See John Bowker, ed., The Oxford Dictionary of World Religions (Oxford, New York: Oxford University Press, 1997), 1070. 
K: I think within the Orthodox tradition we have two models of ascetic endeavour, which split to some extent the integrity of the external and internal battle of St. Antonius of the 3rd century. The first model emphasised more the internal endeavour and is based on the apophatic way of knowing God. We find such a spiritual way, for example, in Father Soprony of Essex. He followed the tradition of Hesychasm together with the praxis of the Jesus prayer. Father Sophrony concentrates a lot on the role of apatheia, that is the mastery and cleansing of all passions, but the Hesychast prayer does not mean for him just the practice of hes$y c h i a$ as an instrument. In the battle with sin, repentance plays the most important role. ${ }^{48}$ For him, there is a huge difference between those who want just to contemplate and those who want to repent. The second type is again represented for me by Mother Maria Skobtsova, whose way of ascetic struggle is aimed especially externally, to the world. The struggle between good and evil is the struggle for any deformation of God's image in people, which for her means the struggle for those in need. The discernment for her is based on commandments of love: to love God and to love fellow man. ${ }^{49}$ Even if she doubts, even if she is afraid that this is just her imagination, her idea, the objective indications are the two commandments.

If I am faced with two paths and I am in doubt, then even if all human wisdom, experience, and tradition point to one of these, but I feel that Christ would have followed the other - all my doubts should immediately disappear and I should choose to follow Christ in spite of all experience, tradition, and wisdom that are opposed to it. ${ }^{50}$

F: Maybe we should think about discernment which stands between the dualistic language of good and evil? Is there any example of it?

K: Yes, I think of the example of God's Mother. When we speak of spiritual discernment, we often use again the metaphor of light for good and dark for evil, but there are also shadows, the states 'in between'. This stage 'in between' stands above the dualism of good and evil. If we look at God's Mother and her doubt in hearing Gabriel's

48 See Archimandrite Sophrony, Saint Silouan, the Athonite (Crestwood: St. Vladimir's Seminary Press, 1999), 180-181.

49 See Mother Maria Skobtsova, 'Types of Religious Life,' in Mother Maria Skobtsova: Essential Writings, 140-186; here 175.

50 Ibid., 174. 
words, we see that doubts are an important part of the process of discernment. I think doubts are not positive or negative but the value of them depends on where doubts lead us. Again, here the hermeneutic of future plays its role.

\section{Part V: Discernment as Individual and Communal}

M: But perhaps we cannot speak about the discernment of good and evil on the individual level only. What are your thoughts on the communal aspect of discernment?

F: I think it is a 'communal discernment of spirits' which Christianity suggests as a tool for this. Perhaps it is what we need to investigate theologically - the question of how we recognise good and evil. I personally find Scripture, Church tradition, and a life of prayer as guides for communal discernment. What tools does community have to be able to discern anything?

K: Yes, I think we definitely have to make the difference between the discernment aimed at the community and also the discernment of individuals: (i.) The discernment of spirits has to be understood as a gift from God. In Paul, we have the gift described mainly in I. Cor 12:1-13. Here in Paul, we see that the gift of discernment is aimed at the community of believers. This passage does not pertain to individuals. Communal discernment through history has ended up in schisms or in judging extreme teachings as heresies. (ii.) Individual discernment does not stand in isolation from the communal one, but still, it differs. The big issue here is how we discern. It is not just by judging, but also by intuition, by love. As here within the Orthodox spiritual practice, we have to say by heart, as the heart is understood as the very centre of people. As Olivier Clément puts it: 'The dividing line between good and evil goes through the heart of every person (...) from good to evil it is just one step (...) but then from evil to good also. ${ }^{51}$ Here, discernment should not be mistaken by a needed difference without which real communion does not exist as without difference there cannot be any real unity. The perfect depiction of unity in diversity is Rublev's icon of the Trinity.

M: As I said earlier, I perceive all three aspects of discernment intrinsically as a dialogue between various people sharing one world

51 Clément, Tělo pro smrt a pro slávu, 17. 
and their life of faith in God. ${ }^{52}$ That presupposes an individual level of discernment, while being in communication with the others' search and answers. We find God in Christ in a concrete community, ${ }^{53}$ where one hears the word of God in the proclamation of sin and forgiveness, in the Sacraments, and in the calling to follow Christ.

M: As we speak about the communal aspect of discernment can you think of any example of how a theological insight into the notion of good and evil may be helpful in a current public debate in your context?

K: I cannot think about a current debate explicitly, but I am sure that generally a theological insight of what is good and evil influences what is deeply human. If, together with Mother Maria Skobtsova, to fight against evil means to fight for God's image in us but also in others,$^{54}$ then it has an impact also on our context in which we live. However, we must be careful here not to project our own selfish images into others. The mirrored, narcissistic reflection of our own self onto others is dangerous and again means the deformation of others rather than freeing them. The deformation means often also the violent overcoming of evil by good that is objectified, that is only a tool where the other person becomes a victim of good, a-prosopon, someone without a face..$^{55}$ Thereby, Vladimir Solovyov speaks to me a lot in his iconic approach to good. The truth cannot ever be separated from searching for good and beauty at the same time. To isolate one of them means to end up in a kind of idolatry. If we isolate good from truth and beauty, it can turn to be only an attempt without any meaning, or we have only abstract truth, which is just an empty concept, or we have isolated beauty which becomes an idol. ${ }^{56}$ Not-incarnated truth and good can easily be turned into dogmatism and moralism. The advantage of

52 Here, I draw primarily on Staniloae's notion of dialogue that I discussed mainly in the fourth charter of my book Michaela Kusnierikova, Acting for Others: Trinitarian Communion and Christological Agency (Minneapolis: Fortress press, 2017).

53 As Bonhoeffer puts it, Christ exists as a Church-community in the sense of an actual fellowship and their life together, living a life of discipleship. Cf. Dietrich Bonhoeffer, The Cost of Discipleship (New York: Simon and Schuster, 1995). Also: Dietrich Bonhoeffer, 'Life Together: Prayerbook of the Bible,' in Dietrich Bonhoeffer Works: Volume 5, ed. Geffrey B. Kelly (Minneapolis: Fortress Press, 2005).

54 See Mother Maria Skobtsova, 'The Second Gospel Commandment,' in Mother Maria Skobtsova: Essential Writings, 45-60; here 60.

55 See Clément, Télo pro smrt a slávu, 21.

56 See Vladimir Solovyov, 'Три речи в память Достоевского [Three Talks in Memory of Dostoevsky],' Accessed April 3, 2019, http://www.vehi.net/soloviev/trirechi.html. 
beauty is that it cannot exist without corporality and materiality, and that means that when we discern we have to take into account a real person, not an abstract illusion.

F: I agree here that Christian discernment as a part of searching for religious Christian identity is in fact searching for human identity in the light of (or an experience of) Christian revelation. This could be a particular perspective which Christians could bring to the society-wide, public process of discernment and realisation of ideals of humanity and contribute towards forming the basic human identity. All who want to fully realise their own humanity naturally search for the absolute horizon of humanity. Christians are not following Jesus Christ for the sake of their own salvation but for the sake of the whole humanity's welfare. From my perspective, the idea of discernment in general is connected to life and as such it can be linked also to the ancient practice of mystagogy. An inspiration may be found in Karl Rahner's treatment of mystagogy. ${ }^{57}$ Rahner's primary concern is to make mystagogy relevant for contemporaries and regard discernment as the practice of an ongoing hermeneutical re-reading of experience and tradition. Such a 're-reading' includes not only written texts but also practices. The ancient texts and practices of the Church may help people today to understand their life experiences. But for this to be the case, they must be reinterpreted in order to become meaningful, anew, and once again. ${ }^{5}$

M: I think of the examples of Dietrich Bonhoeffer, Samuel Štefan Osuský, Jozef Bučko, and others, who were able to discern between good and evil not only after the fact or theoretically, but when, for example, as Bonhoeffer said 'the masquerade of evil' is taking place and act (or refrain from activity) accordingly. Today, when we hear about the 'evil from Istanbul' referring to the document 'Convention on Preventing and Combating Violence against Women and Domestic Violence of the Council of Europe', or evil being imported by migrants, or as we face the rise of Christian-based right-wing movements and political parties, such a theological voice would be helpful not only within the churches but also in the public-political space. To me, the Roman-Catholic priest Anton Srholec was an example of a contemporary in Slovakia who,

57 See, for instance, Karl Rahner, 'The Concept of Mystery in Catholic Theology, in Theological Investigations 4 (London: Darton, Longman \& Todd, 1966).

58 Cf. David Regan, Experience the Mystery: Pastoral Possibilities for Christian Mystagogy (London: Geoffrey Chapman, 1994), 33. 
living out his faith, became a kind of a public spiritual figure (here I allude to the concept of public intellectual/theologian) who was able to convey the message of goodness rooted in the Gospel not only to Christians but also to the public.

Katerina Kočandrle Bauer Protestant Theological Faculty, Charles University The Ecumenical Institute

Černá 9 11555 Praha 1 Czech Republic E-mail: katerinabauer3@gmail.com

František Štěch Protestant Theological Faculty, Charles University Theology \& Contemporary Culture research group

Cerná 9 11555 Praha 1 Czech Republic

E-mail: stechf@etf.cuni.cz

Michaela Kušnieriková C. S. Lewis Bilingual High School Haanova 28 85104 Bratislava

Slovakia E-mail:m.kusnierikova@yahoo.de 